\title{
Relacje pomiędzy formalnymi i nieformalnymi elementami ladu aksjonormatywnego w ujęciu empirycznym
}

\section{Wprowadzenie}

W niniejszym opracowaniu zostaną omówione wyniki badań empirycznych nad długookresowymi tendencjami zachodzącymi w procesie powstawania formalnych źródeł prawa. U podstaw prowadzenia tych badań legło założenie, iż pojawianie się wspomnianych tendencji jest nieuchronnym rezultatem występowania zależności pomiędzy działalnością legislacyjną (wprowadzaniem do obiegu społecznego norm sformalizowanych prawnie) i ewolucją niesformalizowanych reguł, norm czy instytucji tworzących porządek panujący w obrębie danej zbiorowości (który może być określany jako istniejący w jej obrębie ład aksjonormatywny, układ instytucjonalny itp.).

\section{Metody badań empirycznych nad relacjami pomiędzy formalnymi i nieformalnymi elementami ladu aksjonormatywnego (porządku instytucjonalnego)}

\subsection{Podejście „mikro”}

Badania nad relacjami pomiędzy formalnymi i nieformalnymi elementami ładu aksjonormatywnego (regułami, normami, dyrektywami ${ }^{1} \mathrm{czy}_{\text {instytucjami }}{ }^{2}$ należącymi do tego porządku) można prowadzić z - co najmniej-dwóch perspektyw.

1 Pomijam rozróżnienie pomiędzy pojęciami takimi jak norma, reguła, rozkaz, dyrektywa, wypowiedź dyrektywalna itp., gdyż - z punktu widzenia celu niniejszych rozważań - nie jest to niezbędne. Charakter sporów dotyczących desygnatów tych pojęć dobrze oddaje wypowiedź K. Opałka i J. Wróblewskiego: „Dla jednych np. norma to tyle, co przepis, dla innych jest regułą skonstruowaną lub wyinterpretowaną z przepisu, lub reguła jest łączną nazwą dla norm i przepisów - ale nazwa «reguła» bywa również odnoszona tylko do gier. W myśl teorii imperatywnej norma i rozkaz to jedno, ale wedle innych poglądów rozkaz jest tylko pewnym rodzajem norm konkretno-indywidualnych. Podobnie niejasna jest nazwa «zasada» - można np. utrzymywać, że normy to zasady postępowania, można jednak również przyznawać zasadom charakter norm szczególnego rodzaju: «zasadniczych» czy «podstawowych»" (K. Opałek, J. Wróblewski, Prawo. Metodologia, filozofia, teoria prawa, Warszawa 1991, s. 193).

$2 \mathrm{~W}$ prawie, ekonomii i socjologii pojęcie instytucji rozumiane jest bardzo różnie, por. np. T. Gaweł, M. Klimczak, Pojęcie instytucji w prawie i ekonomii, [w:] B. Polszakiewicz, J. Boehlke 
Po pierwsze, możliwe jest badanie struktury poszczególnych schematów działania, jakimi posługuje człowiek dla osiągnięcia określonego celu działania. Otóż, człowiek, dążąc do zaspokojenia jakiejś potrzeby, posługuje się regułami (normami, instytucjami czy - ujmując rzecz najszerzej - gotowymi rozwiązaniami dylematu decyzyjnego) różnego rodzaju, zarówno formalnymi, jak i nieformalnymi ${ }^{3}$, powiązanymi ze sobą funkcjonalnie w pewną całość, którą można nazwać schematem działania lub kompletem normatywnym ${ }^{4}$. Najważniejsze elementy konstrukcyjne takiego schematu działania, to: 1) cel i 2) warunki jego realizacji, obejmujące elementy (reguły, normy, instytucje, rozwiązania), bez uwzględnienia których osiągnięcie celu w ogóle nie jest możliwe (można je nazwać elementami „,rdzenia”) oraz elementy zwiększające lub zmniejszające prawdopodobieństwo osiągnięcia celu działania (można je nazwać elementami „miękkimi”) $)^{5}$. Elementy te pochodzą głównie z trzech podstawowych zasobów informacji o adekwatnych rozwiązaniach: 1) norm prawa, 2) reguł gospodarowania, 3) reguł pozyskiwania dóbr z tytułu przynależności do zbiorowości. Każdy z tych zasobów obejmuje trzy rodzaje elementów: 1) sankcje negatywne, 2) sankcje pozytywne $\left.{ }^{6}, 3\right)$ pozostałe.

(red.), Ead instytucjonalny w gospodarce, Toruń 2005. Na przykład w socjologii instytucje są rozumiane jako utrwalone wzory działań i zachowań ludzkich, które porządkują interakcje ludzkie i określają ramy prowadzonych przez jednostki gier (ujęcie nowego instytucjonalizmu) lub jako kompleksy ról społecznych skupionych wokół działalności, której celem jest zaspokajanie jakiejś istotnej potrzeby społecznej (B. Szacka, Wprowadzenie do socjologii, Warszawa 2003, s. 132). Dlatego pojęcia: instytucja, reguła czy norma będą dalej używane albo jako synonim pojedynczego rozwiązania dla danej sytuacji decyzyjnej (w sensie zbliżonym do dyrektywy postępowania - reguła), albo dla określenia zespołu rozwiązań powiązanych funkcjonalnie (w sensie istotnego elementu konstrukcyjnego ładu społeczno-gospodarczego - instytucja).

3 Przez elementy formalne będą dalej rozumiane normy prawne, zaś przez elementy nieformalne - inne rozwiązania dylematów decyzyjnych, takie jak reguły gospodarowania, reguły pozyskiwania dóbr poprzez powołanie się na przynależność do zbiorowości itp.

${ }_{4}$ Szerzej na temat koncepcji kompletu normatywnego zob. P. Chmielnicki, A. Dybała, M. Stachura, Reguly działania człowieka gospodarujacego w społeczeństwie jako źródło norm prawnych, Warszawa 2010, s. 56 i n.

5 Używane niekiedy przez prawników pojęcie soft law nie oznacza tego samego (odnosi się do problemu sankcjonowania, a nie do problemu efektywności normy), ale - w niektórych wypadkach - desygnaty obydwu pojęć (soft law i „elementy miękkie”) mogą być te same.

$6 \mathrm{~W}$ przypadku nauk prawnych problem pozytywnych następstw zachowania przewidzianych prawem jest podejmowany bardzo rzadko. W rozumieniu innych nauk społecznych, jak np. socjologia, sankcje to kary i nagrody, oba rodzaje sankcji mogą mieć charakter formalny i nieformalny. Zob. B. Szacka, op. cit., s. 81. Jednym z nielicznych teoretyków prawa, którzy podnoszą ten problem jest Lech Morawski, który pisze: „[...] zwrócić należy uwagę na jeszcze jedną ważną rzecz. Wcześniej mówiliśmy, że prawo, by zapewnić zgodność zachowania się adresatów z normami, odwołuje się nie tylko do sankcji, ale również - i to coraz częściej do różnego rodzaju gratyfikacji, a więc różnego rodzaju nagród, takich choćby jak awanse, ulgi, odznaczenia czy zwolnienia podatkowe. Stosownie do tego można wyróżnić - obok norm sankcjonowanych i sankcjonujących - również normy gratyfikowane, które wskazują, jak powinni- 
Określenie charakteru powiązań pomiędzy wszystkim elementami kompletu pozwala na ustalenie kosztów zastosowania schematu i wysokości wypłaty za podporządkowanie działań człowieka określonemu schematowi (rys. 1).

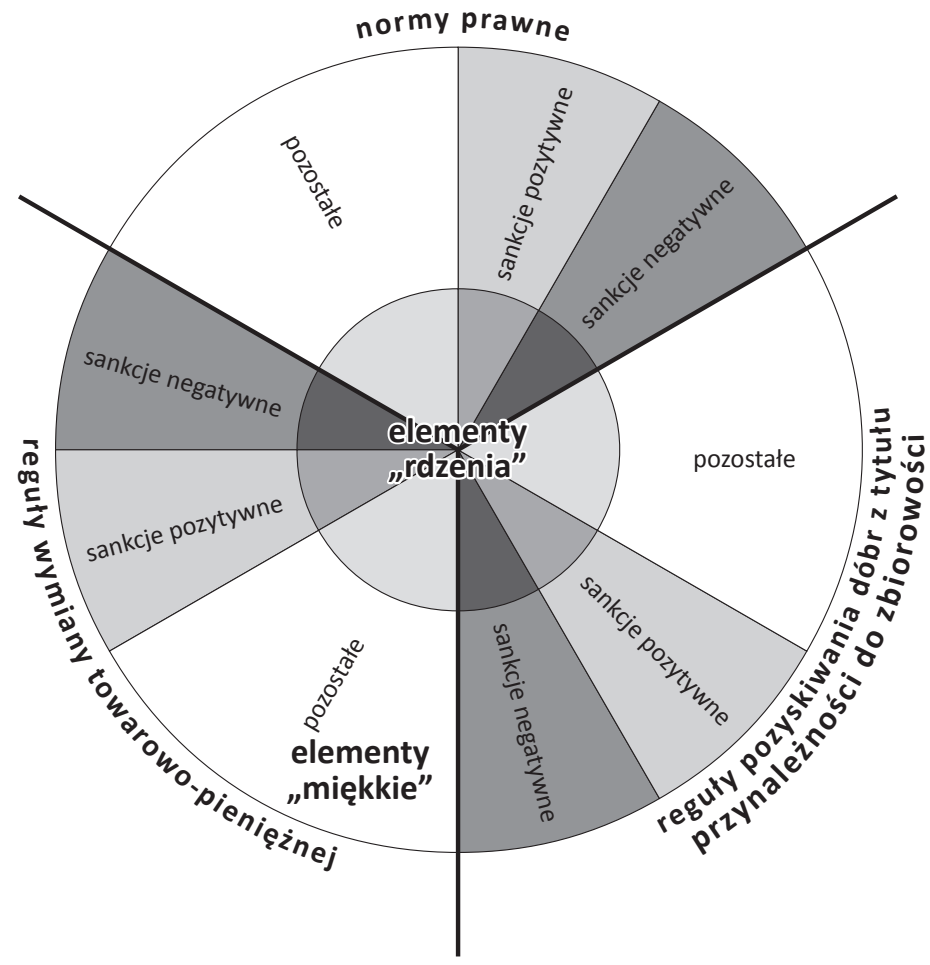

Rys. 1. Komplet normatywny

Źródło: opracowanie własne

Można ustalić elementy należące do „rdzenia” schematu i do części „miękkiej”, w tym sankcje, określić charakter oddziaływań pomiędzy poszczególnymi elementami, katalog kosztów i wypłat, możliwe warianty działania, a także podstawowe rodzaje relacji zewnętrznych kompletu i sformułować wnioski co do jego użyteczności. Byłoby to przedsięwzięcie przypominające mniej więcej badanie poszczególnych instytucji, jednak jego efektem byłoby wykrycie i opisanie - przede wszystkim - rodzajów oddziaływań pomiędzy instytucjami, zachodzących w procesie ich stosowania celem osiągnięcia pewnego rezultatu ekonomicznego i/lub społecznego. Parafrazując, można

śmy się zachować, i normy gratyfikujące, które stanowią przyrzeczenie nagrody na wypadek, gdy adresat normy gratyfikowanej osiągnie określony w niej stan rzeczy”. L. Morawski, Wstęp do prawoznawstwa, Toruń 2005, s. 60 . 
powiedzieć, iż badanie poszczególnych kompletów normatywnych to podejście „W skali mikro” - pamiętając, iż chodzi jednak o sposoby działania upowszechniane i chronione najczęściej w obrębie całej zbiorowości (całego społeczeństwa, całego państwa itp.).

\subsection{Podejście „makro"}

Możliwe jest także prowadzenie badań odnoszących się do efektów działania całego systemu kompletów normatywnych, do rezultatów współoddziaływania zbiorów informacji o regułach (normach, instytucjach), z których pochodzą elementy schematów działania. Nasuwa się tu zastosowanie metody kwantytatywnej, zmierzającej do ustalenia występowania długookresowych tendencji w zakresie ewolucji schematów interakcji zachodzących w społeczeństwie, gospodarce oraz społeczno-gospodarczych przesłanek (kierunków) tworzenia formalnych źródeł prawa. Można powiedzieć, iż byłyby to badania „w skali makro”. Tego rodzaju badania można przeprowadzić metodami statystycznymi.

Prawo jest produktem cywilizacji, dobrem niematerialnym wytwarzanym przez człowieka, za pomocą którego może porządkować i optymalizować przebieg interakcji w zbiorowości, zarówno w sferze tradycyjnie nazywanej prywatną, jak i w sferze publicznej. Za pomocą prawa możliwe jest redukowanie - do akceptowalnego poziomu - kosztów wynikających z kolizji intencji różnych podmiotów, interesów, woli, a także z niedoskonałości komunikacji interpersonalnej, z nieporozumień co do treści komunikatów, wypowiedzi, oświadczeń. Interakcje, których przebieg określany jest za pomocą prawa, pojawiają się w społeczeństwie w zależności od ogólnych zmian stosunków społeczno-gospodarczych. Wytwarzanie każdego dobra, zarówno materialnego, jak i niematerialnego, wynika z pojawienia się jakiegoś zapotrzebowania, popytu na określone dobro. Popyt może być wynikiem swobodnej ewolucji stosunków społeczno-gospodarczych, może być też - do pewnego stopnia - wykreowany. Tak jak na każde inne dobro, może też zmieniać się zapotrzebowanie na określony rodzaj instytucji formalnych, w tym regulacji prawnych. Przykładem mogą być zmiany, jakie pojawiają się w prawie finansowym w związku ze zmieniającą się sytuacją sektora bankowego, wynikającą z wprowadzania na rynek nowych instrumentów finansowych wiążących się z większym ryzykiem inwestycyjnym itp. Skoro prawo ewoluuje wraz z ewolucją stosunków społeczno-gospodarczych i jest częścią stale ewoluującej większej całości - ładu aksjonormatywnego (porządku instytucjonalnego), to dlaczego nie badać zmian zachodzących w procesie tej ewolucji, tak aby móc stwierdzić, jakie tendencje długookresowe występują w procesie tworzenia dobra niematerialnego, jakim jest prawo?

Jeśli dopuszczamy takie cele poznawcze, to od razu nasuwa się szereg konkretnych pytań badawczych: 
1. Czy zmiany ilościowe występujące $\mathrm{w}$ procesie tworzenia źródeł prawa mają charakter przypadkowy, czy też mają charakter regularności i tendencji długookresowych pozostających w stałym oddziaływaniu ze zmianami sytuacji makroekonomicznej? Czy ilość źródeł prawa dotyczących określonych spraw wynika z zasad techniki legislacyjnej i woli politycznego centrum decyzyjnego, czy też zależy od popytu na określone regulacje, kształtowanego przez zjawiska zachodzące w gospodarce?

2. Czy kwantytatywna metoda badania procesu tworzenia źródeł prawa może doprowadzić do odkrycia wskazanych powyżej prawidłowości? Czy wzajemne oddziaływanie reguł wymiany towarowo-pieniężnej i norm prawnych można stwierdzić empirycznie?

3. W jaki sposób zmiany zachodzące $\mathrm{w}$ gospodarce korelują $\mathrm{z}$ tworzeniem norm prawnych określonego rodzaju? Czy tworzenie norm prawnych określonego rodzaju wyprzedza pewne zjawiska makroekonomiczne, czy też tendencje występujące w gospodarce wyprzedzają tworzenie określonych regulacji prawnych?

4. Czy zmiany prawa powodują zmiany w gospodarce, czy tylko dyskontują zmiany zachodzące w gospodarce? W jaki sposób korelują ze sobą reguły zachowań rynkowych i reguły budowy struktur społecznych? Czy system norm prawnych stymuluje postawy zorientowane na zdobywanie dóbr w ramach konkurencji na wolnym rynku, czy też sprzyja budowaniu postaw zorientowanych na pozyskiwanie dóbr za sam fakt przynależności do społeczeństwa?

5. Jakie powiązania zachodzą pomiędzy działaniem istniejących już reguł a tworzeniem nowych reguł służących realizacji celów człowieka? Jakie są kierunki ewolucji zasobu reguł (norm, insty tucji, rozwiązań), jakimi kieruje się człowiek? Jak często nowe regulacje tworzą sposoby działania o wyższym stopniu komplikacji, o wyższym stopniu wyspecjalizowania, a jak często tworzą sposoby działania stanowiące alternatywę dla już istniejących metod? Czy rozrost i komplikacja systemu normatywnego ma przyczyny wewnętrzne czy zewnętrzne?

$\mathrm{Z}$ pewnością odpowiedzi na te pytania mogłyby przynieść badania empiryczne nad formalnymi źródłami prawa, uwzględniające metody kwantytatywne. Warto zaznaczyć, że potrzeba prowadzenia systemowych badań empirycznych procesu legislacyjnego, wykorzystujących narzędzia badawcze z zakresu statystyki, jest postulowana już od dawna.

W naukach prawnych badania koncentrują się w głównej mierze na opracowywaniu zasad budowy norm prawnych pod względem dogmatycznym, na klasyfikacji oraz na wykładni logiczno-językowej norm niezbędnych dla teorii i praktyki. Natomiast dociekania nad genezą i przyczynami różnego rodzaju faktów prawnych stoją na dalszym planie, przy czym opracowania takie podejmowane są po większej części przez historyków prawa, socjologów, psychologów i ekonomistów. Jest rzeczą bezsporną, że „dobre prawo”, zarówno w stadium tworzenia, jak i stosowania go w praktyce, powinno opierać się na solidnej znajomości warunków społeczno-gospodarczych w szerokim tego słowa znaczeniu. Do tego potrzebne są właśnie badania empiryczne, w których prawoznawcy nie powinni być wyręczani przez badaczy innych dyscyplin społecznych, 
zainteresowanych problematyką prawną tylko pośrednio w ramach planów naukowo-badawczych. Tymczasem opracowania tego rodzaju pojawiają się dość rzadko i raczej przypadkowo, chociaż w badaniach empirycznych nad prawem, w każdej niemal dziedzinie, występują zjawiska masowe dające się mierzyć wprost bądź „uilościowić” na drodze pośredniej za pomocą różnego rodzaju „równoważników zachowania się” opracowanych przez specjalistów-prawników we współpracy ze statystykami. Przypadki takiej współpracy należą, niestety, do rzadkości. Inną jest rzeczą, że nauka wchodzi w erę metryzacji i komputeryzacji, która zapewne nie ominie prawoznawstwa ${ }^{7}$.

Jednak, mimo upływu blisko 40 lat od napisania tych słów, badanie źródeł prawa metodami kwantytatywnymi nadal należy do rzadkości ${ }^{8}$. Znane są jedynie nieliczne przykłady badań nad prawem powszechnie obowiązującym uwzględniające metody ilościowe - dotyczą one pojedynczych, wybranych problemów, takich jak prawo autorskie albo kwestie techniczno-prawne (np. częstość powoływania określonych podstaw prawnych).

\section{Metodyka badań empirycznych zastosowana w projekcie}

Jak się wydaje, do tej pory nie powstał żaden projekt badawczy, który stawiałby sobie za cel badanie metodą kwantytatywną (albo kwalifikatywno-kwantytatywną) całego procesu ustawodawczego w danym kraju na przestrzeni dłuższego okresu - kilkunastu lub kilkudziesięciu lat.

Projekt, którego wyniki zostaną omówione (w wyborze) w niniejszym opracowaniu, jest bodaj pierwszym przedsięwzięciem naukowym stawiającym sobie za cel przeprowadzenie tego rodzaju badań. Stanowi on kontynuację projektu obejmującego badanie społeczno-gospodarczych przesłanek ustaw uchwalanych w Polsce w latach 1990-20079. Oparty był w zasadzie o tę samą metodykę, jednak z pewnymi istotnymi różnicami, które zostaną wyeksponowane poniżej.

Punktem wyjścia było sformułowanie cząstkowych zagadnień badawczych na podstawie teoretycznych założeń co do występowania podstawowych grup czynników ekonomicznych, społecznych i psychologicznych determinujących kwestie poruszane w normach prawnych (regułach działania poddanych zabiegom formalizacyjnym $)^{10}$. Pytania te odnosiły się do reguł działań opartych o zasady gospodarki towarowo-pieniężnej, do reguł budowy zbiorowości i reguł

7 Z. Rogoziński, Charakter i znaczenie metody statystycznej $w$ procesie tworzenia i stosowania prawa, [w:] idem, Metody statystyczne w prawoznawstwie, Warszawa 1976, s. 16-17.

8 Dogmatyka prawa posługuje się prawie wyłącznie metodą kwalifikatywną. Zob. A. Pieniążek, M. Stefaniuk, Socjologia prawa, Kraków 2005, s. 100.

9 Wyniki tego projektu zostały opisane książce: P. Chmielnicki, A. Dybała, M. Stachura, Reguły działania człowieka gospodarujacego w społeczeństwie jako źródło norm prawnych, Warszawa 2010, s. 139-272. Autorem prezentowanej w tej publikacji koncepcji badań oraz założeń teoretycznych, na których koncepcja ta została oparta, a także kierownikiem projektu badawczego, którego wyniki zostały zamieszczone w książce jest P. Chmielnicki.

${ }^{10}$ Ibidem. 
pozyskiwania dóbr z tytułu przynależności do zbiorowości oraz do przejawów transformacji systemu schematów działania. Pytania posłużyły do oceny niektórych cech aktów prawa powszechnie obowiązującego i do stwierdzenia, czy o przebiegu procesu legislacyjnego decydowały wspomniane czynniki, w jakim stopniu i jak często. Ocena wystąpienia czynnika (ewaluacja) była dokonywana w siedmiostopniowej skali, stosownie do znaczenia, jakie odgrywał czynnik przy tworzeniu aktu prawnego. Uzyskane w ten sposób dane zostały zagregowane w ciągi czasowo-liczbowe (szeregi czasowe), przy czym jednostką czasu był 1 rok, zaś zmiany wielkości liczbowych zostały zaprezentowane graficznie na wykresach. Na koniec przeprowadzono analizę porównawczą zagregowanych danych o tendencjach $\mathrm{w}$ procesie legislacyjnym $\mathrm{z}$ typowo zagregowanymi danymi makroekonomicznymi obejmującymi ten sam okres.

Przyjęto, iż wystąpienie czynników determinujących zamiar legislacyjny będzie badane tylko w odniesieniu do jednego rodzaju źródeł prawa: ustaw uchwalonych w Polsce w latach 1990-2011. Za tym wyborem przemawiało kilka przyczyn. Wzgląd na potrzebę zakończenia badań empirycznych w jakimś rozsądnym czasie skłaniał do rezygnacji z badań źródeł prawa niższej rangi, takich jak rozporządzenia i akty prawa miejscowego, nie wspominając już o prawie wewnętrznym. Ilość tych źródeł prawa (kilkadziesiąt tysięcy samych rozporządzeń), nawet zakładając zbadanie tylko jakiejś reprezentatywnej próby, niezwykle utrudniłaby poczynienie jakichkolwiek ustaleń. Istniała jednak przyczyna ważniejsza, niż tylko względy organizacyjne: polski system tworzenia formalnych źródeł prawa umożliwia - na tym poziomie ogólności, który został przyjęty do badań - pominięcie analizy aktów rangi niższej niż ustawa. Akty niższej rangi mają w Polsce w zdecydowanej większości charakter stricte wykonawczy, a ich normy rozwijają jedynie postanowienia ustaw, czyli powielają kierunki działań legislatora, nie mogą więc zmienić na szerszą skalę obrazu tendencji w zakresie przesłanek społeczno-gospodarczych stanowienia prawa. Analizie poddano więc zdecydowaną większość ustaw, jakie zostały uchwalone przez Sejm RP w latach 1990-2011. Pominięto akty o charakterze techniczno-prawnym, np. publikacje tekstów jednolitych ustaw, które nie wnosiły żadnego novum normatywnego. Bardzo istotną kwestią jest to, iż poszczególne ustawy, w przytłaczającej większości przypadków (co najmniej w 95\%), odnoszą się do wyodrębnionego wątku stosunków społeczno-gospodarczych (tzn. jedna ustawa z reguły służy osiągnięciu wyodrębnionego celu społeczno-gospodarczego - „załatwieniu jednej sprawy”, co można łatwo stwierdzić na podstawie lektury uzasadnień projektów ustaw). W sumie poddano analizie 2838 ustaw, czyli niemal wszystkie ustawy, jakie wprowadzały novum normatywne (średnio na rok przypadło około 129 ustaw, jednak liczba ta znacznie się różni w poszczególnych latach).

Jak już wspomniano, opisane wyżej dane empiryczne poddano analizie z punktu widzenia określonych, cząstkowych zagadnień (pytań) badawczych. Sformułowane pytania oczywiście nie odnosiły się do tytułów ustaw ani 
do rozwiązań techniczno-prawnych, lecz do przesłanek ekonomiczno-społecznych, jakie były wskazywane w uzasadnieniach projektów. Dlatego udzielenie odpowiedzi (dokonanie ewaluacji) wymagało znajomości nie tyle samego aktu, ile uzasadnienia jego projektu - bowiem tylko w uzasadnieniu projektu ustawodawca zdradza cel regulacji, przesłanki społeczno-ekonomiczne jej tworzenia i prognozowane następstwa. $Z$ uwagi na przebieg procesu legislacyjnego mogą się one częściowo różnić od przesłanek, jakie zadecydowały o ostatecznym kształcie ustawy. Jednak - na szczęście dla omawianego projektu badawczego - w Polsce nie są to nigdy różnice drastyczne, które całkowicie zmieniałyby ocenę materialnych źródeł ustawy (ustawy są prawie zawsze uchwalane mniej więcej zgodnie z intencjami projektów, gdyż akceptowane są niemal wyłącznie projekty przygotowane przez podmioty reprezentujące większość polityczną w Sejmie; jest to cecha wynikająca z polskiego modelu systemu parlamentarno-gabinetowego).

Proces ewaluacji polegał na tym, iż każda $z$ ustaw była oceniana w odniesieniu do cząstkowych pytań badawczych w skali siedmiostopniowej. Nie zastosowano potencjalnie najprostszej, trójstopniowej skali $(-1,0,1)$, gdyż chodziło o uwypuklenie wyraźnych różnic w doniosłości społeczno-gospodarczej pomiędzy niektórymi regulacjami.

Dla każdego z zagadnień badawczych sformułowanych wobec każdej z 2838 ustaw należało podać jedną z następujących wartości:

$$
\begin{array}{lllllll}
-3 & -2 & -1 & 0 & 1 & 2 & 3
\end{array}
$$

Ich znaczenie przedstawia się, jak poniżej.

Wartość „-3”: ustawa jednoznacznie przeciwdziała efektowi opisanemu w pytaniu (generuje formalną barierę, jednoznacznie koliduje, reguluje wprost przeciwnie) i ma to duże znaczenie w skali całego społeczeństwa lub przynajmniej jego dużej części.

Wartość ,-2": ustawa nie wprowadza całkowitej bariery, odnoszącej się w szerokim wymiarze podmiotowym i przedmiotowym do efektu zakładanego w pytaniu badawczym, ale tworzy regulacje, które wyraźnie utrudniają osiągnięcie efektu, choć - być może - w ograniczonym zakresie, na niezbyt dużą skalę; inaczej mówiąc: regulacje znacznie utrudniają osiągnięcie efektu, choć nie niweczą go całkowicie.

Wartość „,-1”: ustawa ma raczej negatywny wpływ na pojawienie się efektu zakładanego pytaniem, ale pośredni i trudny do oszacowania.

Wartość „0”: ustawa nie ma żadnego znaczenia dla wywołania efektu zakładanego w pytaniu.

Wartość „1”: ustawa ma raczej pozytywny wpływ na pojawienie się efektu zakładanego w pytaniu, ale pośredni i trudny do oszacowania; inaczej mówiąc: tworzy sprzyjające warunki. 
Wartość „2”: ustawa wprowadza regulacje, które wprost mogą posłużyć do osiągnięcia zakładanego efektu, choć - być może - w ograniczony sposób i nie w każdej sytuacji.

Wartość „3”: ustawa wprowadza regulacje, które muszą doprowadzić do zakładanego efektu, są z nim absolutnie zbieżne i mają duże znaczenie dla jego osiągnięcia w skali całego społeczeństwa lub przynajmniej dużej jego części.

Należy zaznaczyć, iż w opisywanej edycji badań (za lata 2008-2011) praca nad ewaluacją przebiegała nieco inaczej niż w poprzedniej edycji projektu (obejmującej lata 1990-2007). Poprzednio opracowanie każdej ewaluacji było dokonywane wspólnie przez jednego ze specjalistów z dziedzin: ekonomia, socjologia, psychologia oraz przez prawnika. Każda ewaluacja była weryfikowana co najmniej trzykrotnie, aby do minimum wyeliminować możliwe rozbieżności interpretacyjne. $\mathrm{W}$ edycji omawianej $\mathrm{w}$ ramach niniejszego artykułu przyjęto, iż trzech specjalistów (prawnik, socjolog, ekonomista) będzie dokonywało ewaluacji zupełnie niezależnie, zaś z ich indywidualnych wyników zostanie wyciągnięta średnia. Chodziło o to, aby sprawdzić, czy nawet osoby niemające wcześniejszego doświadczenia $\mathrm{z}$ opisanym sposobem dokonywania ewaluacji moga efektywnie zastosować pierwotną metodykę projektu i czy bez bezpośredniej wymiany poglądów z inną osobą wykonującą ewaluację praca ewaluacyjna okaże się równie wartościowa, co w przypadku edycji pierwszej.

W trakcie procesu ewaluacji nie były czynione żadne podsumowania cząstkowe. W związku z tym liczba badanych ustaw i dokonywanych ewaluacji uniemożliwiała stawianie jakichkolwiek prognoz co do sumarycznych wartości ewaluacji w poszczególnych latach. Był to zabieg celowy, mający zredukować do minimum szanse na sugerowanie się bieżącymi efektami czynności ewaluacyjnych.

Zastosowano matematyczne metody przekształcania ewaluacji nadanych przez specjalistów względem każdego z pytań w szeregi czasowe. Utworzone w ten sposób szeregi stanowią zmienne (cechy) mierzalne, których realizacje obserwowane są rok po roku. Zmienne te posłużyły m.in. do graficznej ilustracji (w postaci wykresów) zmienności ewaluacji nadawanych w kolejnych latach ${ }^{11}$.

Generalnie, zastosowano dwa podstawowe warianty modelowania matematycznego: sumy ewaluacji i ich przyrosty - określane jako wariant „zliczanie”, zaś ewaluacje średnie i ich przyrosty - określane jako wariant „średnie”. Nie wchodząc w szczegóły obydwu sposobów dokonywania obliczeń, na użytek niniejszej publikacji wystarczy wyjaśnić, iż za pomocą wariantu „zliczanie” z grubsza rzecz biorąc można sprawdzić samą wartość ewaluacji przypadającą na dany rok i dane pytanie badawcze, czyli mniej więcej ukazuje to „natężenie” prac legislacyjnych, natomiast wariant ,średnia” jest bardziej zorientowany na ukazanie znaczenia

${ }^{11} \mathrm{Na}$ temat metod statystycznych opisanych w niniejszym opracowaniu zob. M. Sobczyk, Statystyka, Warszawa 1991; R. Magiera, Modele i metody statystyki matematycznej, Wrocław 2002. 
społeczno-gospodarczego uchwalanych regulacji - innymi słowy, czy za „ilością” kryje się też ,jakość” (czy zainteresowanie ustawodawcy danym problemem przekłada się nie tylko na liczbę tworzonych źródeł prawa, lecz także na ich doniosłość dla stosunków społeczno-gospodarczych). Pomocniczo, zastosowano także sposób tworzenia kolejnych szeregów czasowych, które nazwane są szeregami typu „odcięcie”. Celem, jaki przyświecał tworzeniu tego typu szeregów, było wychwycenie jedynie pozytywnych albo zdecydowanie pozytywnych (odpowiednio: negatywnych albo zdecydowanie negatywnych) ewaluacji $\mathrm{w}$ danym roku, przy równoczesnym pominięciu wszystkich pozostałych ewaluacji, czyli ewaluacji zerowych i negatywnych albo (odpowiednio) zerowych i pozytywnych ${ }^{12}$.

\section{Przykłady rezultatów badawczych}

W dalszej części niniejszego opracowania omówiono wyniki prac badawczych na wybranych przykładach. Szczegółowe ustalenie źródeł i mechanizmu powstawania tendencji w zakresie poszczególnych zagadnień omówionych poniżej wymaga dalszych rozległych badań. Dlatego należy zastrzec, iż rozważania odnoszące się do różnych szczegółowych aspektów wyników badań empirycznych mogą mieć jedynie charakter roboczych hipotez, wymagających osobnej weryfikacji.

Zanim przejdziemy do poszczególnych zagadnień badawczych, warto zapoznać się z wykresem przedstawiającym rozkład liczby badanych uzasadnień projektów ustaw na przestrzeni poszczególnych lat (rys. 2).

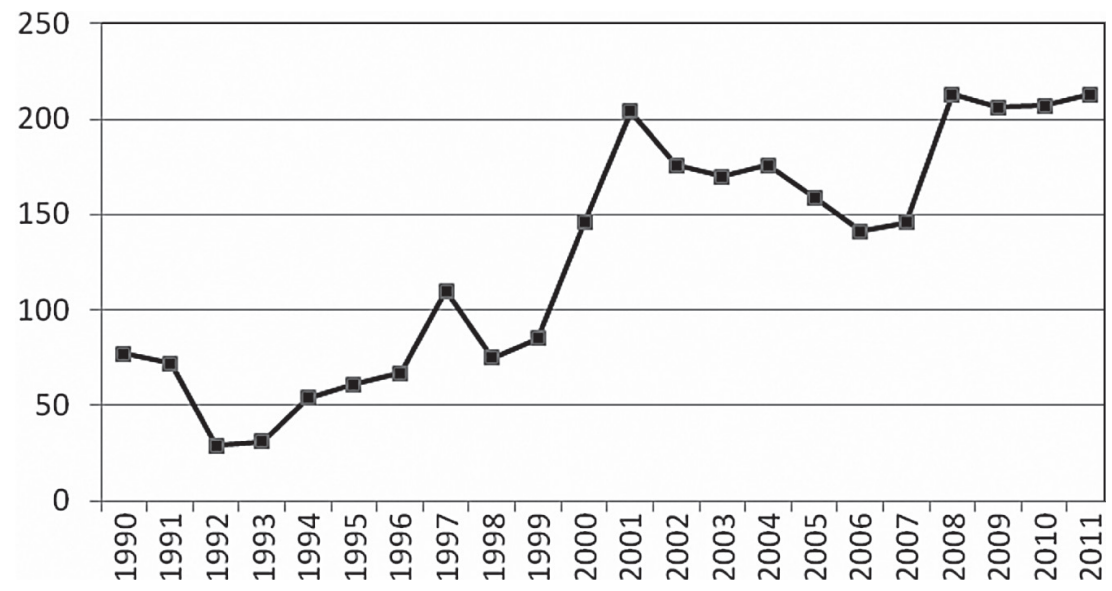

Rys. 2. Liczba badanych uzasadnień projektów ustaw

Źródło: opracowanie własne

${ }^{12}$ Szerzej na temat przebiegu matematycznego modelowania wyników badań zob. M. Stachura, [w:] P. Chmielnicki, A. Dybała, M. Stachura, op. cit., s. 172-181. 
Znajomość wykresu prezentującego liczbę badanych aktów (w przybliżeniu odpowiada on wykresowi liczby wszystkich ustaw, jakie zostały uchwalone $\mathrm{w}$ badanym okresie) $\mathrm{w}$ rozbiciu na poszczególne lata jest o tyle istotna, że pozwala stwierdzić, czy wykres dotyczący konkretnego zagadnienia badawczego stanowi mniej więcej odzwierciedlenie ogólnej liczby tworzonych ustaw, czy też nie. Jeżeli tak, oznacza to, iż pewne zagadnienia są przedmiotem regulacji ze stałym - w przybliżeniu - natężeniem, albo, mówiąc inaczej, pozostają obiektem stałego, proporcjonalnego do ogólnego natężenia prac legislacyjnych, zainteresowania ustawodawcy. Podobnie można interpretować każdy wykres „średniej”, jeżeli przedstawia on tendencję mniej więcej stałą: ani wzrostową, ani spadkową. Większa dynamika wzrostu (lub spadku) wartości odnoszących się do pewnego zagadnienia, niż dynamika wzrostu (lub spadku) ogólnej liczby uchwalanych w danym roku ustaw świadczy o wzmocnieniu (lub osłabieniu) czynników determinujących formalizację określonych rodzajów schematów działania. Wykres ukazuje, iż liczba uchwalanych ustaw systematycznie, dość szybko rosła w okresie pierwszej dekady po upadku PRL, aż do $2001 \mathrm{r}$. (wzrost z poziomu około 50-100 uchwalanych ustaw na początku lat 90. do poziomu 250-300 ustaw na początku lat dwutysięcznych). Później tendencja szybkiego wzrostu uległa wyhamowaniu i od pewnego czasu liczba uchwalanych ustaw utrzymuje się na podobnym poziomie, mniej więcej dwukrotnie wyższym niż na początku badanego okresu.

Poniżej omówiono wybrane wyniki badań $z$ obydwu edycji projektu, tj. pierwszej (za lata 1990-2007) i drugiej (obejmującej lata 2008-2011), prezentując ich rezultaty zbiorczo.

\section{Przypadek nr 1}

Pytanie badawcze dotyczyło kwestii, czy wyegzekwowanie regulacji sprzyja powstawaniu poczucia, że jakieś dobra (świadczenia materialne lub niematerialne: przedmioty, pieniądze, praca, wrażenie bezpieczeństwa, ładu, przewidywalności itp.) są przyznawane z powodu - wyłącznie albo prawie wyłącznie - przynależności do jakieś grupy społecznej (państwo, grupa etniczna, grupa zawodowa itp.), a nie stanowią ekwiwalentu za wykonaną lub wykonywaną nadal pracę. Czy regulacja sprzyja powstawaniu poczucia, że wysiłek wkładany w pozyskanie dobra na zasadzie ekwiwalentu za pracę nie jest tak efektywny (tak opłacalny), jak postaranie się o pozyskanie dobra z tytułu przynależności do zbiorowości, gdyż o pozyskaniu dobra (o rozdziale dóbr między członków społeczeństwa, o podziale wspólnie wypracowanego zysku, o możliwości zatrzymania samodzielnie wypracowanego zysku dla siebie) nie decyduje indywidualny wysiłek włożony w pracę i własna wola, ale inne kryteria? 


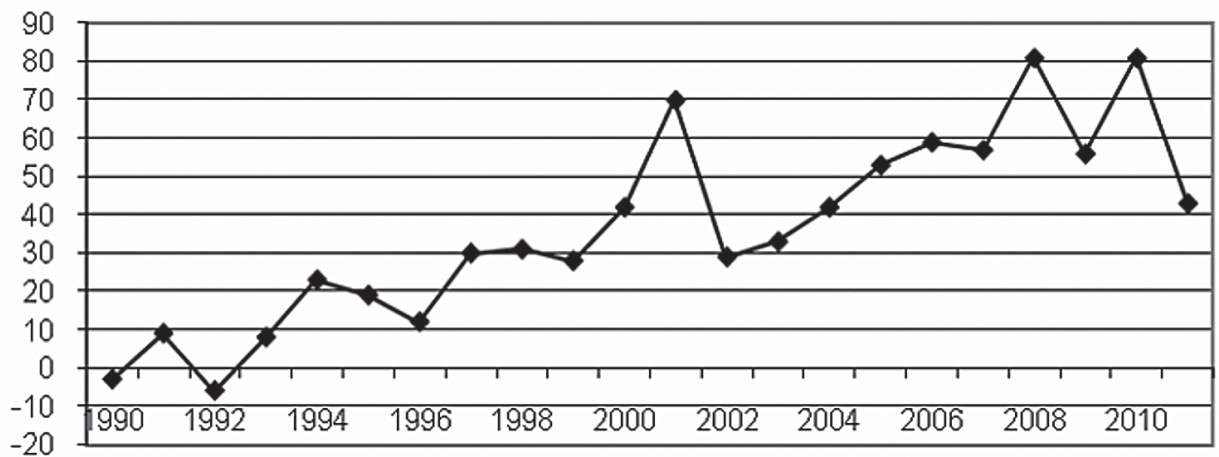

Rys. 3. Wykres uzyskany przy zastosowaniu metody ,zliczanie” Źródło: opracowanie własne

Komentarz

Natężenie regulacji dotyczących pozyskiwania dóbr (zaspokojenia potrzeb) na zasadzie powołania się na status w zbiorowości przez bardzo długi okres wykazywało stałą tendencję wzrostową (rys. 3). Regulacji takich powstawało bardzo wiele, ich przedmiotem było np. kompleksowe wprowadzenie szerokiej gamy środków pomocy społecznej: wprowadzenie zasiłku przedemerytalnego dla bezrobotnych, szczególna ochrona pracowników urzędów administracji państwowej zwalnianych w związku z reformą administracji; podwyższenie wysokości świadczeń alimentacyjnych wypłacanych zastępczo przez skarb państwa; określenie dopłat $\mathrm{z}$ budżetu państwa w związku z realizacją zobowiązań przedsiębiorstw państwowych do sprzedaży samochodów osobom prywatnym, które dużo wcześniej uiściły zadatek itp. W latach 1990-2007 do wyraźnego przełamania tendencji wzrostowej doszło tylko jeden raz - w latach 2001-2002 i moment ten pokrywa się z latami głębokiego kryzysu gospodarczego, który zmusił rządzącą koalicję SLD-PSL do szeregu drastycznych redukcji wydatków z budżetu państwa. Jednak już od roku 2003 tworzenie regulacji odnoszących się do omawianego pytania badawczego powróciło na drogę stabilnego wzrostu. Zwraca uwagę, iż o ile w omawianym okresie ogólna liczba badanych aktów wzrosła ok. dwukrotnie (zob. rys. 2), to liczba aktów ewaluowanych pozytywnie w stosunku do pytania badawczego wzrosła aż ok. sześciokrotnie! Dopiero w ostatnim okresie (lata 2006-2011, czyli głównie w okresie objętym drugą edycją projektu) zaczyna zaznaczać się przełamanie tej wieloletniej tendencji wzrostowej, co można odczytywać m.in. jako ograniczenie (ew. zatrzymanie rozbudowy) funkcji państwa opiekuńczego.

\section{Przypadek nr 2}

Pytanie badawcze dotyczyło kwestii, czy regulacja może być oceniona tak, że wprowadza metodę alokacji dóbr (dóbr materialnych lub niematerialnych, otwarcia dostępu do jakiegoś sposobu zaspokojenia potrzeb) według 
takiego kryterium, które mogłoby być uznane za sprawiedliwe (racjonalnie uzasadnione) przez każdą lub prawie każdą grupę społeczną. Informacja dodatkowa: istotne - w kontekście pytania badawczego - było to, czy regulacja rzeczywiście wiąże się z alokacją dobra od jednego odrębnego podmiotu do drugiego odrębnego podmiotu (np. od skarbu państwa na rzecz jakiejś grupy społecznej), ewentualnie czy może chodzić o przydzielenie nowego dobra dla kogoś, natomiast różne modyfikacje kompetencji aparatu władzy publicznej nie wiązały się bezpośrednio z treścią pytania. Ponadto ewaluacja o wartości dodatniej była uzasadniona tylko w sytuacjach, kiedy rozwiązanie nie wzbudza kontrowersji wśród przeważającej części społeczeństwa - tu konieczne było odwołanie się do wiedzy o stanie ładu aksjonormatywnego konkretnego społeczeństwa, tzn. że nie można było wskazać żadnej albo prawie żadnej grupy, która mogłaby kwestionować regulację z uwagi na własny uzasadniony interes; ewaluacja o wartości ujemnej była zasadna wówczas, kiedy regulacja mogła wzbudzić kontrowersje wśród różnych grup społecznych (np. wierzących i niewierzących), w szczególności w przypadkach naruszenia zasady równego traktowania jednostek spełniających te same kryteria dostępu do dóbr.

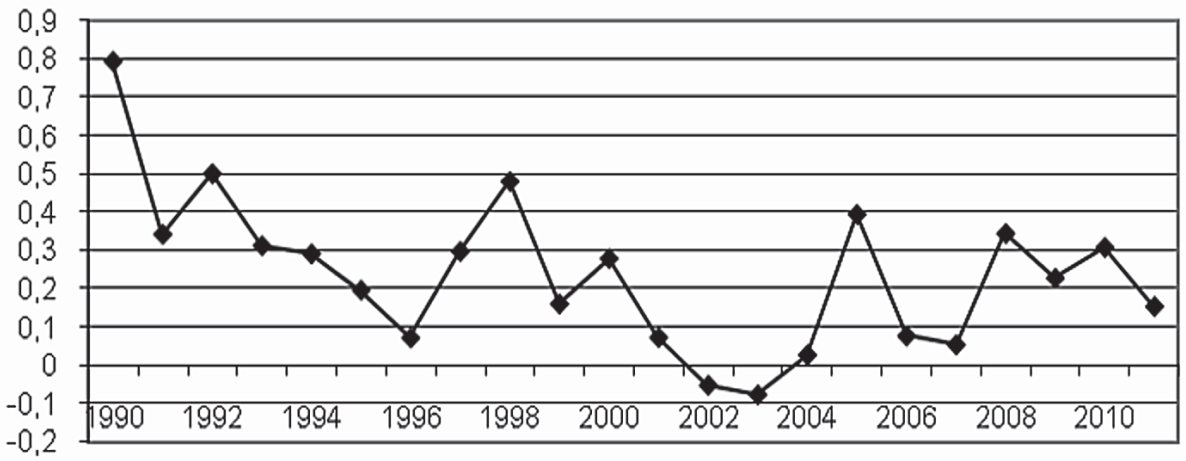

Rys. 4. Wykres uzyskany przy zastosowaniu metody „średnia”

Źródło: opracowanie własne

Komentarz

Omawiany przypadek stanowi dobry przykład różnicowania efektów poznawczych, jakie dawały różne warianty modelowania matematycznego zastosowanego w ramach obu edycji projektu. Wykres przedstawiony na rys. 4 powstał przy zastosowaniu metody „średnia”. Wskazuje na występowanie wieloletniego trendu spadkowego w latach 1990-2003. Oznacza to, że w tym przedziale czasu regulacje oparte na metodzie alokacji dóbr według kryterium, które w odczuciu społecznym mogłoby być uznane za sprawiedliwe czy racjonalnie uzasadnione, ustępowały przed regulacjami stanowiącymi ich odwrotność, czyli przed regulacjami opartymi na przesłankach partykularnych. 
Pozytywnie ewaluowane były regulacje dotyczące takich kwestii, jak: zniesienie zróżnicowania ze względu na płeć w zakresie wieku emerytalnego pracownika uprawniającego pracodawcę publicznego do rozwiązania stosunku pracy (stosunek pracy mógł być rozwiązany z kobietami o 5 lat wcześniej niż z mężczyznami), zrównanie prawa kobiet i mężczyzn do urlopu wychowawczego, zrównanie statusu różnych związków wyznaniowych z Kościołem katolickim, zwolnienie od podatku dotacji przyznawanych osobom dotkniętym klęską żywiołową, ustalenie maksymalnej wysokości diet radnych z organów stanowiących jednostek samorządu terytorialnego itp. Natomiast negatywne ewaluacje dotyczyły aktów, których przedmiotem były np. specjalne ulgi cenowe w nabyciu mieszkań ,zakładowych” (stanowiących własność publiczną) przez pracowników niektórych przedsiębiorstw państwowych; specjalne zasady wynagradzania nauczycieli ze środków publicznych, gwarantujące im dużo większą stabilizację finansową niż w przypadku innych grup zawodowych itp. Po roku 2003 daje się zauważyć wyhamowanie tej tendencji. Można to intuicyjnie powiązać z rosnącym naciskiem społecznym na budowę państwa prawa, w którym tworzenie norm powszechnie obowiązujących odwołuje się do zasady równości. $Z$ wykresu na rys. 4 nie wynika jednoznacznie, jaki był w omawianym okresie stan regulacji, które odwoływały się do przesłanek partykularnych. W latach 2008-2011 można zauważyć np. ogólną lekką tendencję spadkową. Obraz sytuacji staje się jednak znacznie klarowniejszy przy zastosowaniu metody „odcięcie przez -1” (rys. 5).

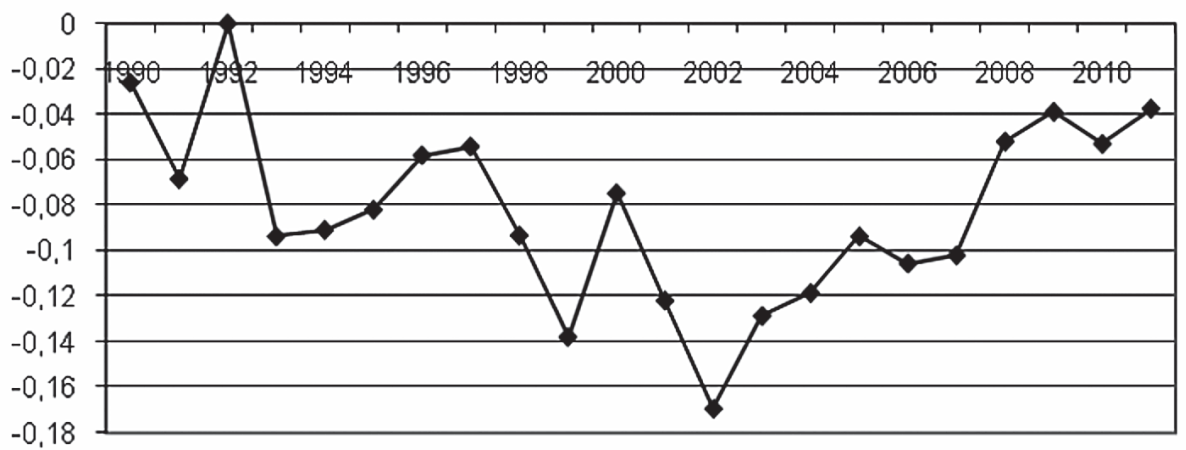

Rys. 5. Wykres uzyskany przy zastosowaniu metody „średnia - odcięcie przez -1”

Źródło: opracowanie własne

Teraz można już stwierdzić, że od roku 2002 zaznaczyła się bardzo wyraźnie tendencja do ograniczania regulacji odwołujących się do przesłanek partykularnych. Można powiedzieć, iż dzięki zastosowaniu metody „odcięcie” obraz sytuacji został znacznie ,wyostrzony”, wynik badawczy zyskał na transparentności. 


\section{Przypadek nr 3}

Pytanie badawcze dotyczyło kwestii, czy regulacja wzmacnia ochronę powszechnie uznanych (respektowanych w społeczeństwie demokratycznym) praw jednostek (podmiotów prywatnych), czy sprzyja ich realizacji z wyprzedzeniem interesów państwa (np. czy wzmacnia środki kontroli władzy przez obywatela, czy daje ludziom szerszy dostęp do informacji o poczynaniach władzy, czy poszerza dostęp obywateli do bezpośredniego podejmowania decyzji politycznych). Informacja dodatkowa: chodziło o regulacje dające jakieś korzyści bezpośrednio jednostkom lub związkom osób prywatnych, a nie pośrednio, np. poprzez dofinansowanie działalności państwowych zakładów pracy, które dają im zatrudnienie.

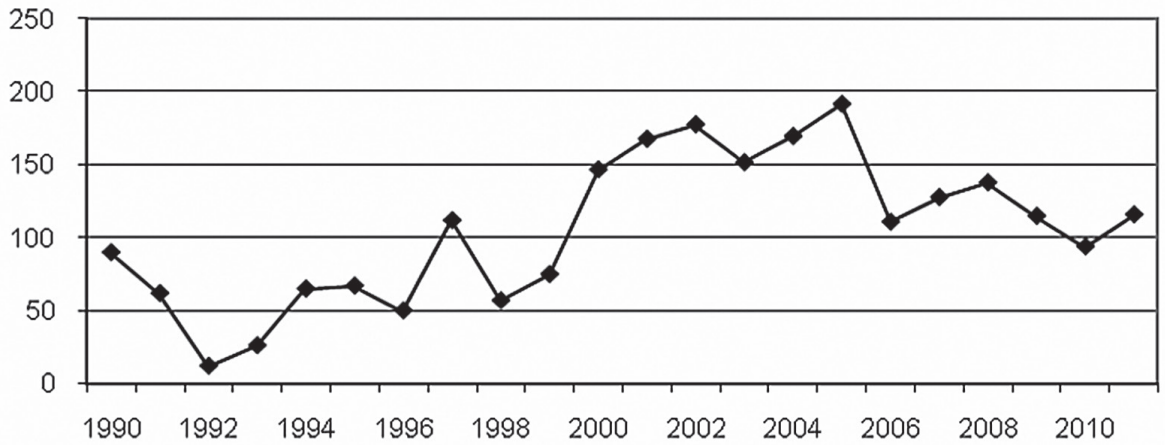

Rys. 6. Wykres uzyskany przy zastosowaniu metody „zliczanie”

Źródło: opracowanie własne

Komentarz

Omawiany przypadek stanowi dobry przykład różnicy w efektach poznawczych, jakie dawało zastosowanie metody ,zliczanie” albo metody ,średnia”. Wykres na rys. 6, który powstał dzięki zastosowaniu metody „zliczanie” sugeruje wieloletnią tendencję wzrostową, utrzymującą się aż do roku 2005. Jak już wspomniano, za pomocą metody „zliczanie” z grubsza biorąc można sprawdzić samą wartość ewaluacji przypadająca na dany rok i dane pytanie badawcze, czyli mniej więcej ukazuje ona „,natężenie” prac legislacyjnych związanych z danym problemem legislacyjnym. Ewaluacje o wartościach dodatnich dotyczyły regulacji, których przedmiotem było np.: przyznanie inicjatywy ustawodawczej grupom obywatelskim; zniesienie zasady utraty zasiłku z pomocy społecznej w przypadku podjęcia zatrudnienia i wprowadzenie w to miejsce zawieszania wypłat gwarantowanego zasiłku okresowego; wydłużenie czasu urlopu macierzyńskiego o ponad 50\%; ułatwienie uzyskiwania pomocy pieniężnej przez kombatantów i osoby represjonowane poprzez uproszczenie procedur i przeniesienie struktur administracyjnych odpowiedzialnych za dystrybucję świadczeń bliżej miejsca zamieszkania osób uprawnionych; organizacja udzielania pożyczek i kredytów dla studentów szkół wyższych; zrekompensowanie 
niepodwyższania wynagrodzeń pracowników służb publicznych itp. Wykres metody „zliczanie" sugeruje, że przewaga natężenia prac nad regulacjami wzmacniającymi ochronę powszechnie uznanych praw jednostek (podmiotów prywatnych) nad regulacjami, które sprzyjają realizacji tych praw z wyprzedzeniem interesów państwa wykazywała wyraźną tendencję wzrostową (ok. czterokrotny wzrost w latach 19902005). Stąd można by było wysnuć wniosek, iż zaangażowanie percepcji ustawodawcy w sprawach związanych ze wzmacnianiem praw jednostek było coraz większe. Jednak wykres powstały przy zastosowaniu metody „średnia” zmusza do zmiany oceny poczynań legislatora (rys. 7).

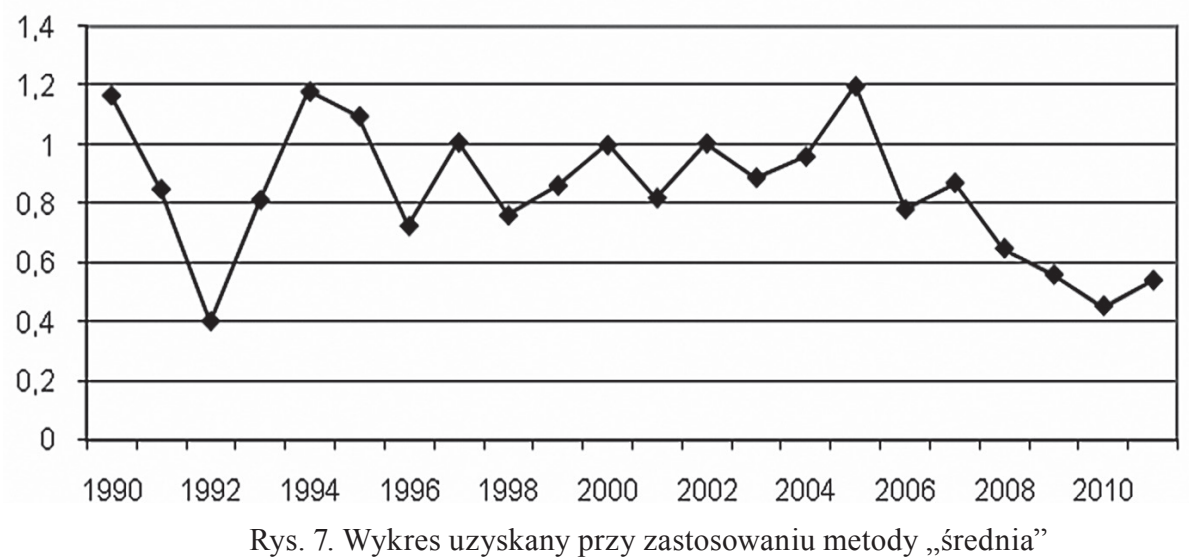

Źródło: opracowanie własne

Jak wspomniano, wariant modelowania ,średnia” jest bardziej zorientowany na ukazanie znaczenia społeczno-gospodarczego uchwalanych regulacji, innymi słowy - tego, czy za „ilością” kryje się też ,jakość” (czy zainteresowanie ustawodawcy danym problemem przekłada się nie tylko na liczbę tworzonych źródeł prawa, lecz także na ich doniosłość dla stosunków społeczno-gospodarczych). Wykres tendencji uzyskany dzięki tej metodzie zdradza prawdziwe oblicze działań legislacyjnych. Dzięki niemu można wnioskować, iż „zainteresowanie” ustawodawcy omawianymi kwestiami w rzeczywistości nie rosło, ale utrzymywało się na podobnym poziomie przez kilkanaście lat, zaś od roku 2005 zaznaczyła się bardzo wyraźna tendencja spadkowa. Być może wynika ona z faktu, iż w Polsce uzyskano już na tyle zadowalający poziom ochrony praw jednostek, że prace legislacyjne dotyczące tej kwestii mogły ulec ograniczeniu - jednak trudno powiedzieć, na ile taka konkluzja byłaby zasadna.

\section{Przypadek nr 4}

Pytanie badawcze dotyczyło kwestii, czy stosowanie regulacji stwarza utrudnienia (podnosi koszty) w osiągnięciu jakiegoś celu działań przedsiębiorcy lub jednostki działającej na wolnym rynku (konsumenta, pracobiorcy), szczególnie 
jakiegoś celu gospodarczego (np. czy stosowanie regulacji powoduje konieczność przeznaczenia większych środków na zobowiązania publiczne, np. podatki, zabezpieczenie socjalne; czy wymaga zaangażowania dodatkowych osób, potrzebnych do spełnienia wymagań stawianych przez władze; przeznaczenia większej ilości czasu na załatwienie danej sprawy). Informacja dodatkowa: pytanie dotyczy kosztów schematu działania, a nie wypłat, zatem przeznaczenie dla kogoś dodatkowych środków (np. zwiększenie wynagrodzenia, świadczenia transferowego) nie uzasadniało ewaluacji o wartości ujemnej (nie było odwrotnością opisanej wyżej sytuacji); ewaluacja o wartości ujemnej była natomiast uzasadniona w stosunku do regulacji redukującej koszty (zdejmującej obciążenia, jak np. zmniejszenie podatków).

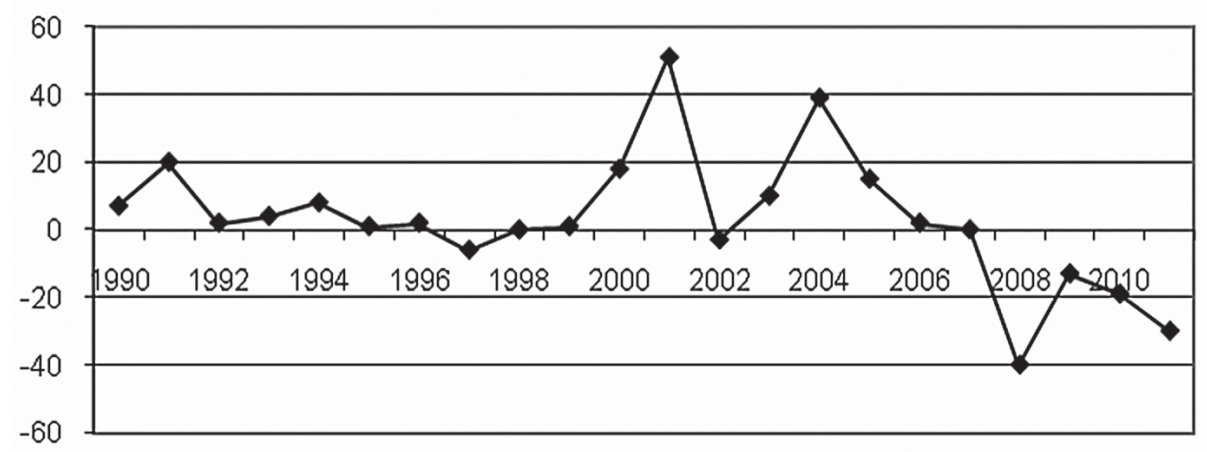

Rys. 8. Wykres uzyskany przy zastosowaniu metody „zliczanie”

Źródło: opracowanie własne

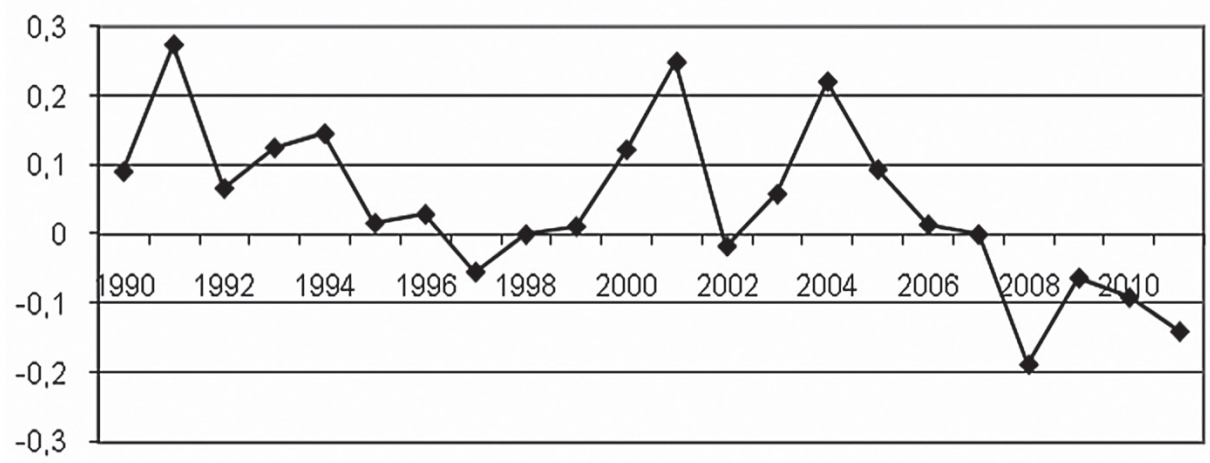

Rys. 9. Wykres uzyskany przy zastosowaniu metody „średnia”

Źródło: opracowanie własne

Komentarz

Tym razem, analizowany przypadek stanowi ciekawy przykład możliwości uzyskania wyraźnej koherencji między wynikami zastosowania obu metod modelowania matematycznego (,zliczanie” i ,średnia”) (rys. 8 i 9). Dodatnie ewaluacje 
dotyczyły regulacji podnoszących koszty transakcyjne i tworzących bariery wejścia, a więc takich, które za przedmiot miały np.: nałożenie podatku od sprzedaży akcji w obrocie publicznym; wprowadzenie mechanizmu stałego podwyższania minimalnego wynagrodzenia za pracę poprzez powiązanie stawki wynagrodzenia minimalnego z wysokością przeciętnego wynagrodzenia w gospodarce; zwiększenie wymiaru składek na fundusz ubezpieczeń społecznych płaconych przez niektóre osoby prowadzące działalność gospodarczą; podniesienie stawek podatku od nieruchomości o 20\%; ustalenie obowiązku ubezpieczenia 50\% powierzchni upraw rolnych od ryzyka wystapienia klęsk żywiołowych; wprowadzenie obowiązku przedsiębiorców zapewnienia odzysku i recyklingu odpadów opakowaniowych i poużytkowych; rozszerzenie opodatkowania transakcji sprzedaży dotyczących pojazdów osobowych, które uzyskały świadectwo homologacji dla pojazdu przeznaczonego do przewozu towarów; wprowadzenie dodatkowych obowiązków przedsiębiorców w zakresie zapobiegania i ograniczania powstawaniu hałasu. Natomiast ewaluacje ujemne dotyczyły regulacji redukujących koszty i znoszących bariery wejścia, jak np.: zwolnienie z wymogu legalizacji zagranicznych dokumentów urzędowych; wprowadzenie ulgi podatkowej z tytułu zakupu nowej technologii; wprowadzenie obniżonych stawek podatku VAT na materiały budowlane; zniesienie obowiązku ubezpieczenia emerytalnego i rentowego dla osób prowadzących działalność gospodarczą, które mają ustalone prawo do renty z tytułu niezdolności do pracy; zniesienie opodatkowania spadków i darowizn dla najbliższych krewnych itp. Na obu wykresach widać właściwie to samo: długookresową tendencję spadkową w całym badanym okresie, przełamaną bardzo wyraźnie jeden raz: w latach 2000-2004 (oczywiście, znacznie „ostrzej” widać tendencję na wykresie uzyskanym metodą ,średnia"). Były to lata związane z dostosowywaniem polskiego prawa do prawa Unii Europejskiej. Polska włączała się do nowego suprasystemu, co wiązało się przeważnie z podwyższeniem różnorakich wymagań, wzrostem szeroko rozumianych kosztów działalności gospodarczej itp. Na ten okres przypada wspomniany wyżej moment kryzysu gospodarczego, co thumaczy „siodło" przypadające na lata 2001-2002 (rządzący starali się „rozkręcić” gospodarkę, a nie dusić ją wyższymi kosztami i wymaganiami). Bardzo wyraźna tendencja spadkowa widoczna jest już po roku 2004 (po wejściu Polski do UE) i zwraca uwagę podobieństwo tej sytuacji do okresu po 1990 r. Po „skokowej” zmianie lat 1989-1990, związanej ze zmianą ustroju polityczno-gospodarczego, nastapiła długoletnia tendencja spadkowa - okres „racjonalizacji kosztów”. Następnie miał miejsce kolejny „skokowy” wzrost kosztów związany z przygotowaniami do wejścia do UE, a następnie - po włączeniu Polski do Wspólnoty - koszty transakcyjne znowu były „racjonalizowane”... Z czego może wynikać taki układ tendencji?

Empirycznie obserwowalny przyrost liczby nowych regulacji zwiększających koszty działania człowieka gospodarującego i zakres formalizacji jego działań ewidentnie ma charakter skokowy. Wiąże się z przełamaniem stanu krytycznej równowagi stosunków społeczno-gospodarczych i przejściem do nowego kompleksu 
wzorów działania (oparcia procesu pozyskiwania dóbr na nowej równowadze systemu kompletów normatywnych). Przełamanie stanu krytycznej równowagi może mieć przyczyny zewnętrzne, związane np. ze zmianami w zasobach gospodarki lub wydarzeniami geopolitycznymi (jak akcesja do wspólnoty międzynarodowej), albo wewnętrzne, związane z mechanizmami rywalizacji o dostęp do najefektywniejszych sposobów pozyskiwania dóbr. Otóż zmiana schematu działania z przyczyn wewnętrznych jest spowodowana niejednakowym tempem spadku użyteczności schematu dla poszczególnych użytkowników i beneficjentów. Część podmiotów, które muszą zrezygnować ze stosowania danego wzoru ze względu na zbyt dużą przewagę innych użytkowników zaczyna zaspokajać swoje potrzeby w trudniejszych warunkach, przez co nowe schematy działania stosowane przez te osoby są bardziej skomplikowane i wymagają poniesienia większych kosztów. Po przełamaniu stanu krytycznej równowagi następuje przejście do innej formuły porządku gospodarczo-społecznego i rozpoczyna się proces optymalizacji zaakceptowanych schematów działania oraz redukcji kosztów związanych z ich stosowaniem. Jednak proces ten ma miejsce w ramach ogólnie wyższego poziomu kosztów funkcjonowania systemu wzorów działania niż w poprzedniej formule.

Należy zaznaczyć, iż omówione wyżej wyniki badań empirycznych są, ogólnie rzecz biorąc, zgodne z ekonomiczną teorią kosztów transakcyjnych - ale nie do końca. Teoria kosztów transakcyjnych zakłada bowiem stały wzrost tych kosztów i nie uwzględnia możliwości występowania dłuższych okresów ich redukcji, podczas gdy prezentowane wyniki badań dowodzą, że rzeczywistość wygląda inaczej: koszty transakcyjne rosną, lecz skokowo, tylko w momentach przełamywania stanu krytycznej równowagi, natomiast następstwem takiej sytuacji jest dłuższy okres „dostosowawczy”, związany z racjonalizacją i redukcją kosztów transakcyjnych i barier wejścia.

\section{Przypadek nr 5}

W tym wypadku pytanie badawcze również dotyczyło kwestii mocno eksponowanej w teorii ekonomii (podobnie jak kwestia kosztów transakcyjnych), a mianowicie tzw. efektu Ringelmanna ${ }^{13}$. Chodziło o to, czy regulacja obciąża jakimś dodatkowym kosztem pozyskanie jakiegoś dobra nie na zasadzie ekwiwalentu za bieżący indywidualny wysiłek (przede wszystkim związany z osobistą pracą zarobkową), lecz z tytułu samego faktu przynależności do społeczeństwa, na zasadzie renty (ang. rent-seeking) ${ }^{14}$ albo „wyłudzenia świadczenia” (czyli

${ }^{13} \mathrm{Na}$ temat efektu Ringelmanna szerzej zob. M. Górnik-Durose, Z. Zaleski, Własność i posiadanie, [w:] T. Tyszka (red.), Psychologia ekonomiczna, Gdańsk 2004, s. 136 i n.

${ }^{14}$ Analiza metod uzyskiwania ,sztucznej renty” jest przedmiotem tzw. teorii pogoni za rentą, zob. G. Tullock, The welfare cost of tariffs, monopolies and theft, „Western Economic Journal” 1976, vol. V; A. Krueger, The political of rent-seeking society, „American Economic Review” 1974, vol. LXIV. 
zachowania, jakie obrazowo określane jest jako ,jazda na gape”). Informacja dodatkowa: zagadnienie dotyczyło głównie uwagi, jaką system państwowy przykłada do walki z „efektem gapowicza”. Ewaluacja o wartości dodatniej była więc zasadna w sytuacji, kiedy np. zaostrzano kryteria uzyskiwania świadczeń transferowych, odejmowano komuś jakiś przywilej, natomiast ewaluacja o wartości ujemnej następowała w sytuacjach odwrotnych.

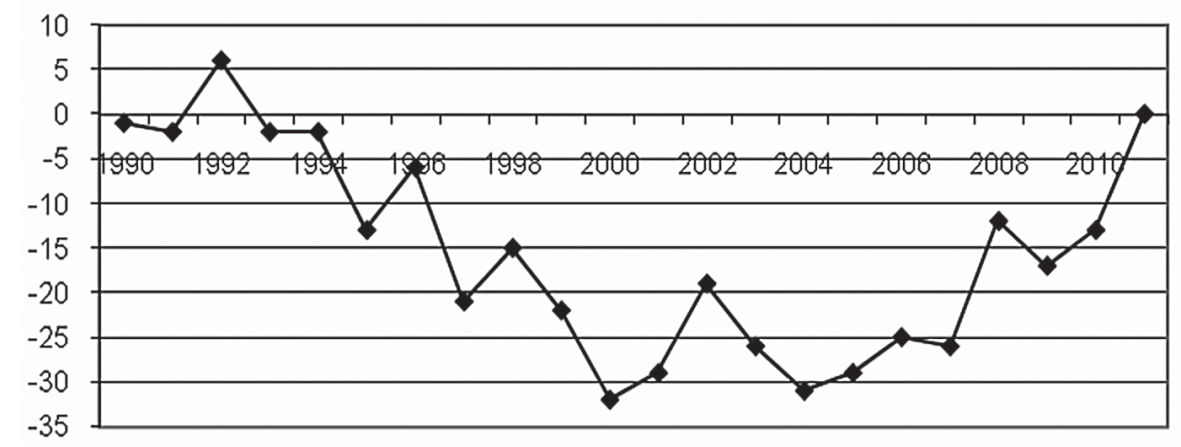

Rys. 10. Wykres uzyskany przy zastosowaniu metody „zliczanie”

Źródło: opracowanie własne

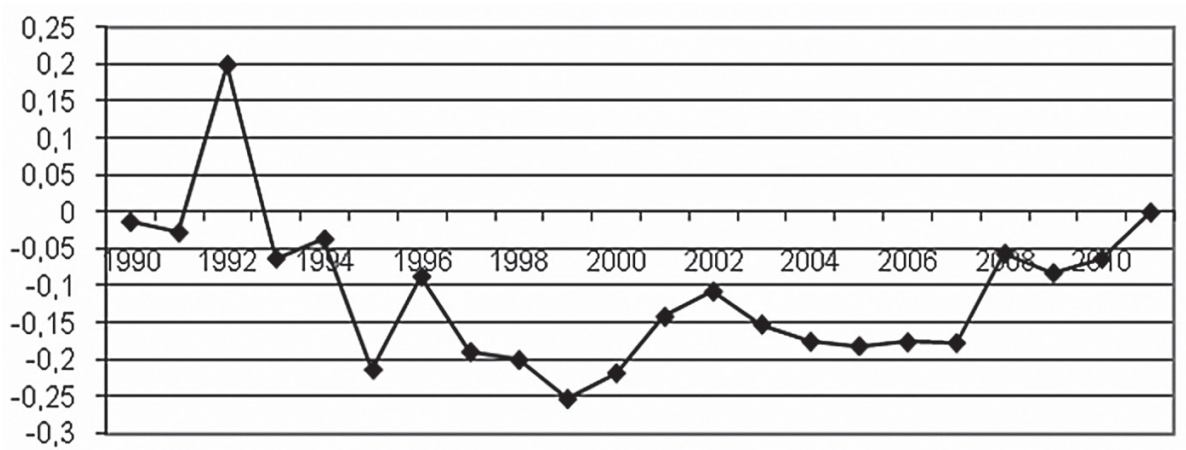

Rys. 11. Wykres uzyskany przy zastosowaniu metody „średnia”

Źródło: opracowanie własne

\section{Komentarz}

Obie metody modelowania matematycznego ujawniają analogiczny obraz tendencji długookresowej (rys. 10 i 11). Najpierw, mniej więcej do roku 2000, dominowały regulacje, które nie tylko nie miały za przedmiot zwalczania „efektu gapowicza”, ale wręcz zachęcały do „pogoni za rentą” (widać wyraźną przewagę ewaluacji ujemnych, a więc aktów, które regulowały w sposób odwrotny od założonego w pytaniu badawczym przeciwdziałania ,jeździe na gapę”). Dodatnie ewaluacje dotyczyły np. ustaw, których przedmiotem było zaostrzenie kryteriów pobierania zasiłku dla bezrobotnych, ograniczenie ulg i zwolnień z opodatkowania 
podatkami lokalnymi. Natomiast ewaluacje ujemne dotyczyły takich regulacji, jak: zwiększenie stawki podatku rolnego od gruntów niezaklasyfikowanych jako użytki rolne, a wchodzących w skład gospodarstwa rolnego; podwyższenie ulg komunikacyjnych dla inwalidów wojennych oraz ich opiekunów; wprowadzenie korzystniejszych - dla uprawnionych do świadczeń - zasad waloryzacji emerytur i rent, na podstawie wzrostu wskaźnika cen towarów i usług w roku poprzednim oraz wskaźnika wzrostu realnych wynagrodzeń; ponad dwukrotne poszerzenie kręgu osób uprawnionych do pomocy materialnej dla studentów (np. stypendia socjalne) itp. Po roku 2000 sytuacja zaczęła się wyraźnie zmieniać, zaś po roku 2004 tendencja już trwale się odwróciła: wystąpił stały wzrost zainteresowania ustawodawcy regulacjami, które mniej lub bardziej bezpośrednio zniechęcają do korzystania z „efektu Ringelmanna”. Można zauważyć, że tendencja ta idzie w parze ze wzrostem regulacji dotyczących alokacji dóbr według takiego kryterium, które mogłoby być uznane za sprawiedliwe (racjonalnie uzasadnione) w odbiorze społecznym, co wydaje się absolutnie logiczną korelacją.

\section{Podsumowanie}

Omówione wyniki badań dowodzą, iż za pomocą metody opisanej w niniejszym opracowaniu możliwe jest odkrycie długookresowych tendencji zachodzących $\mathrm{w}$ procesie tworzenia formalnych źródeł prawa. Ich występowanie można stwierdzić, badając proces tworzenia źródeł prawa empirycznie, metodami kwantytatywnymi. Warto zwrócić uwagę, że nawet bez prowadzenia szczegółowych badań każdego z omówionych przypadków można wskazać logiczne powiązanie wyników badawczych dotyczących przedsięwzięć legislacyjnych z procesami i zdarzeniami zachodzącymi w analogicznym okresie w społeczeństwie i gospodarce.

Jednak spostrzeżenia te mogą pozostać co najwyżej roboczymi hipotezami, jeżeli nie zostaną poparte badaniami empirycznymi opartymi na pierwszej z metod opisanych na wstępie niniejszego tekstu, czyli na badaniach w skali „mikro”. Istotę powiązań pomiędzy normami niesformalizowanymi a normami prawa może wyjaśnić w danym przypadku jedynie zbadanie struktury poszczególnych kompletów normatywnych, analiza celów, korzyści i kosztów, jakie odnoszą się do podmiotów będących adresatami jego funkcjonowania. 